\title{
Legal Implication On Land Right Certificate Issuance In Indonesia
}

\author{
Dr (cand). Novi Sri Wahyuni, S.H., M.Kn. \\ (Legal science doctoral student, Faculty of Law, University of Sumatera Utara, Medan, Indonesia) \\ Prof. Dr. Syafruddin Kalo, SH, M.Hum \\ (Promotor) \\ Prof. Dr. Tan Kamelo, SH, MH \\ (Co Promotor) \\ Dr. OK. Saidin, SH, MH \\ (Co Promotor)
}

\begin{abstract}
Aabstract: The effort to reach legal certainty in land registration law often met many issues, one of them is, even though the right on the land has been issued to the owner, but materially, other people often rule the land. Because of that, in this paper, legal implication on land right certificate issuance in Indonesia is discussed. The method used is normative law research. The result showed that the issuance on land right certificate tend to be implicated with legal certainty of the land, and also the disputes regarding the land in courtroom. Legal certainty of land registration has been regulated in Indonesian Act number 5 of 1960 regarding Agrarian Law, but the legal certainty have not been realized because of the disputes occurred in courtroom. Right certificate on land, is the product of State Administration Officials, resulting the enforcement of Administration law on it. Besides that, according to the legal concept and land provision, the character of the land can be differed into constitutive and declarative in character, the constitutive one is under the authority of administration court of the state, and the declarative one is under the authority of common court. By that, the failure of land certificate issuance can be punished with the state administration law, private law, and also criminal law, if it has the factors of crime in it.
\end{abstract}

Keywords: implication, land certificate, disputes.

\section{INTRODUCTION}

In Indonesia, the development of law is directed to the realization of national legal system based on Pancasila and Indonesian Constitution of 1945, including legal material, enforcer, media and tool, and also the legal culture as the realization of legal country respecting human right to create well behaved, secured, and peaceful society.

One of the realization of development in legal material is legislative product mentioned in Indonesian Act number 5 of 1960 regarding Agrarian basic law, which goal is to control the use, rule, and ownership of the land, and also the right transfer of the land, in supporting the development in national land. Article 19 (1) of this Act stated: "to guarantee legal certainty, land registration is held by the government in every area of Indonesia based on the provision regulated in government regulation".The mentioned land registration is regulated in Article 19 (2) of Agrarian Law, including :a) land measurement, mapping, and entry; b) the listing of rights of land and certain right transfer; and c) administration of evidence, as a strong verification.

The effort to realize legal certainty by doing land registration has often be disputed, by the people who has the certificate and other people who rule the land without certificate. In this situation, what should be done is referring to the principle of nemo plus juris, where no one can give the right more than the right existed. On the other hand, there can be someone, with a land rightfully belong to him, who can be sued in court for not registering the land well according to the administration, because one of the goals of land registration is for legal certainty, but this case tend to happen in court. ${ }^{1}$ Land registration and land certificate issuance will be implicated on the legal certainty guaranty on the right of the land, and also on the disputes in court if legal record or procedural failure existed in right certificate on land issuance, both in administrational court, and common court,

1 Muhammad Yamin. (2006). Problematika Mew ujudkan Jaminan K epastian Hukum A tas Tanah Dalam Pendaftaran Tanah, Professor speech in Agrarian Law field in Law Faculty, in front of open assembly, Universitas Sumatera Utara, Gelanggang Mahasiswa, USU, Medan, 2 September, p.11. 
privately or criminally, if criminalization is proven on the issuance of the certificate. This paper is to discuss the legal implication on right certificate issuance of land in Indonesia. The discussion is including legal certainty of land registration, land right certificate dispute in administration law, and the effort of criminal law. The method used is normative law research.

Legal Certainty of Land Right Certificate

\section{DISCUSSION}

Land registration in Indonesia asserted since 24 September 1961 based on the provision of Article 19 Indonesian Act number 5 of 1960 regarding Agrarian Law is to guarantee the legal certainty and the certainty of land right. The implementation of Agrarian Law is regulated in Indonesian Government Regulation number 10 of 1961 regarding Land registration, which then perfected with Indonesian Government Regulation number 24 of 1997 regarding Land registration. Legal certainty for land right holder can be seen in Article 19 (1) Agrarian Law that to guarantee legal certainty, Land registration is held by the government in every area of Indonesia according to the provisions regulated with government regulation.

Article 1 (1) Agrarian Law stated that land registration is some activities cone by the government continuously and in order, including the collection of physical data and legal data, in map and list, regarding the land and houses, including the administration of letter of evidence of right and ownership of the houses/apartments and certain right occurred because of it. The definitions of land registration are including: the activities, done by government, continuously, in order. The activities means, the registering is done systematically both in administration or operational in measurement, mapping, end entry of the land, and also the administration of certificate as the strong verification.

Done by the government is by Republic Indonesia National Land Authority (Badan Pertanahan Nasional Republik Indonesia) and Land offices in each county/city. It means that the matter of land registration is taken care by one central government institution. This is according to Agrarian Law institution in provision Article 19 (1) ordered that government is to register the land in Indonesia.

The object of land registration is regulated in Article 9 of Indonesian Government Regulation number 24 of 1997:

1. The objects of land registration are:

a. The field of land owned with ownership, cultivation right, building right, and use right.

b. Management right land

c. Benefaction land

d. Ownership of apartments

e. Mortgage rights

f. The country'sland

2. In the matter of the country's land, as the object of land registration as mentioned in paragraph (1) $f$, the registering is done by enter the land of the country in land listing.

All rights on land in paragraph (1) Indonesia government regulation number 24 of 1997 by listing the land in National Defense Institution/land offices and issuing the land certificate which is the copy of the land book is to be given to the rightful as the evidence of his ownership. For country'sland, there is no certificate necessary. The land registration system adhered by Agrarian law is negative publication system, but not a pure negative, but it is what is called as negative with positive factor. Negative publication system in implementing land registration is regarding how far people can trust the true data served by the country as the result of land registration activity implemented. This is also regarding the legal impact, because most people in this matter, use the data, but often the data is proven wrong. Land registration is done with negative publication system which tend to be positive as explained in Article 19 (2) c Agrarian Law which stated that the listing or registering is including the administration of right evidence as a strong verification. Then, in Article 23, 32, and 38 , it is also stated that the register is also a strong verification, this kind of statement will not be able to be found in land registration rule with pure negative publication system.

Indonesian Government regulation number 24 of 1997 regarding Land registration, in taking care of negative publication system asserted the effort in collecting and managing physical and legal data. Physical data of land registration is in land parcels, and legal data is anything attached on the land, for example the legal status of the land, the history, of the land or the owner, individually or in group, both private institution or public, or the government institution. Formally it has been implemented in Indonesia since the regulation in this regard enacted. $^{2}$

2 Speech of The Head of National Land Authority (Badan Pertanahan Nasional/BPN) speech in Seminar of the effectiveness of institution in handling the weak negative publication system of land register, held by Agrarian Study Center in Law Faculty, Trisakti University in 20 March 2002, Jakarta, p. 3-4. 
In order to provide the right physical and legal data, the land registration is first mentioned in Indonesian Government Regulation number 24 of 1997 and its practical regulation including the collection stage until the announcement to provide chance for anyone in objection, followed with the making of measurement letter and the entry in land books and the certificate issuance. New certificate is issued when all data has been completed and no more matter to be disputed, and also the listing of the changes in data maintenance stage. ${ }^{3}$

In the study of Administration Law, certificate is a written document issued by the government (Institution or Administration official) to be used as the evidence of right and verification in land registration. When the certificate is stated as a formal document to prove the ownership of the land, the person holding the certificate is the owner. ${ }^{4}$ When a certificate is stated as a verification of land ownership, then the certificate is not the only evidence of the ownership. ${ }^{5}$

The legal provision regulated in Article 23 and 24 Indonesian Government Regulation number 24 of 1997, it showed a legal construction implying certain evidence to be made as the title that can be used for a person or legal entity to sue the country regarding the existed right of the land. Legally, by holding into this evidence, it is a legal standing to use or legalize the asset as his belonging by issuing the certificate. ${ }^{6}$

As known, in private law concept, ownership is a legal relation which is admitter, respected and undeniable to anyone. Ownership is the source of life for the owner, therefore, the owner must e protected by the country. ${ }^{7}$ Ownership, or property rights is a right with the highest relation to the owner, compared with other rights. The relation between the land and the owner caused a right and obligation or an authority of the land, which said by Lisa Whitehouse " property is basic to the social welfare, people seek it, nations war it, and no one can do without it". ${ }^{8}$ Property rights or ownership of land is attached to the owner as long as they don'ttransfer it. ${ }^{9}$ Its also what we found if we studied what John Locke taught regarding this property right which stated that Ownership of property is a natural right and that the purpose of Government is to protect and preserve natural property right. ${ }^{10}$ Copyright is a human right which must be respected and the country need to protect it. The teaching or theory regarding property right which then put in the Constitution as human right which must be protected as mentioned in Article $28 \mathrm{H}$ and $28 \mathrm{G}$, in the amendment of Indonesian Constitution of 1945. The implementation of legal protection guaranty of the property right related to the land, then explained further in Agrarian law by the country.

Related to the matters above, as consequence, it is regulated that to the land of adat right, by law, it is to be changed based on the Country'sadmission on the land ownership because the law is converted as the new eights and the kind of rights created by Agrarian Law. The coutry's admission created land certificate model with legal character of declarative or declaratoir. Besides this, the country should accommodate the right on land occurred from the land status outside the land ruled by the society. This right is issued based on the action of the government which is the settlement of certificate model with legal character of constitutive. ${ }^{11}$

Land Right Certificate Disputes in Administration Law

In implementing the land registration to the right holder on land, an evidence is given according to the data in land offices. Based on the evidence, anyone can easily prove that he is the rightful owner. The data existed in the land office is open for public in need of the information regarding he right of the land. ${ }^{12}$ This is

$3 \quad$ Ibid., p.4.

$4 \quad$ Boedi Harsono (1980). Beberapa A nalisis Tentang Hukum A grarian, bagian 3, Jakarta: Era study Club, p. 1

5 Boedi Djatmiko Hadjatmodjo. (2015). "Karakter Hukum Sertifikat Hak", http://sertifikattanah.blogspot.com/, 10 Mei 2010, accessed January 2015.

$6 \quad$ Ibid.

7 L.B. Curzon (1999). Land Law.Seventh edition, Great Britain: Pearson Education Ltd. p.8-9.

$8 \quad$ Jesse Dukemenier. (1991-1992). Property. Gilbert Law Summaries, p. i.

$9 \quad$ Hari Chand. (1994). Modern Jurisprudence, Kuala Lumpur: International Law Book series. p. 261.

10 John Locke. "Second Treatise on Government".dikutip oleh Rock Deborah. (2001). Property Law \& Human Rights, First Published, London: Blackstone Press Limited Aldine Place. p. 3.

11 The term beschikking is translated sometimes as decision or settlement, and also the state administration term is often used differently. This is as regulated in Indonesian law number 5 of 1986.

12 Boedi Harsono (2003). Hukum A graria Indonesia, Sejarah Pembentukan Undang-Undang Pokok A graria, Isi dan Pelaksanaannya, version I National Land Law, Jakarta: Djambatan, p. 80 
according to the open principle in land registration, where the current principle demand the well management of land registration data continuously, so that the data saved in the land office will be adjusted with the reality, and the society will be able to achieve the explanation regarding the right data every time. For that, open principle is enacted.

But the issues here are, how far the truth of the data served is, and how far law is protecting the person doing the legal action regarding the lands which right has been registered based on the data in land offices or the evidence letter issued by the land office if then the land registration in right certification on land is proven to be a failure. Land right certificate is a product of Administration official so administration law is enforced to it. On the legal action, someone as administration official can do an action included as an unlawful action both because of this fault or failure in fulfilling his duty. ${ }^{13}$

These actions will result a failed certificate, both because of the failure of the legal subject or law in the certificate. Failures may happen in land registration process. ${ }^{14}$ Failure in certificate making can happen because of the fraud (bedrog), missed-direction (dwaling), or force (dwang), in the physical data making or in the legal data in the land book. By that, the resulted certificate can be canceled by law. And for the subject triggered the failure, then his action is included in unlawful action (onrechtmatigedaad). If the action s done with the nation;s media and tool, then it can be categorized as misuse of authority of Administration officials. ${ }^{15}$ 15)

Prof. Van der Pot mentioned four requirements which has to be fulfilled so that the settlement can be enacted:

1. It must be made by the authorized media or tool (bevoegd).

2. Because the settlement of one'sintention (wilsverklaring), the forming of the intention shall not contain any legal damage (geen juridische gebreken in de wilsvorming).

3. The settlement must be given a form (vorm) which is decided in one regulation as the basis and the maker must also concern the procedure in making the settlement as to be made as it should be according to the rules.

4. The content and goal of the settlement must be adjusted to the content and goal of basic rule. ${ }^{16}$

If one of the requirement is not fulfilled, then the related settlement become the unofficial settlement, for example: the settlement made by a person or official with no authority (on bevogd), the settlement is made because of a fraud (bedrog), the settlement is not right according to the procedure based on law (rechtmatige) and the settlement is not fulfilling the goal of the basic rule (doelmatige) or has been misused (detournamen de pauvoir). ${ }^{17}$

Legal action of the Government in registering the land and issuing the certificate to raise legal awareness and create the rights and obligations to certain person must fulfill the requirements and shouldn'thave any failure both regarding technical aspect or legal aspect. The failure in these aspects can cause cancelation on the certificate. Physical or legal data failure in land registration will delete the legal certainty factor on the right of the land, so that the rightful owner will be at disadvantage position. The failure will also cause misinformation in National Defense Institution as the country's tool which impact will also create out of order land administration. ${ }^{18}$

In law, one decision is legal (rechsmatig) when the decision has fulfilled certain requirements by law. By fulfilling these requirements, the decision will have legal power (rechtskrach) to be implemented, if not, the decision is un-legal and can be cancelled (nietig). ${ }^{19}$ As stated by Van der Pot, there are 4 requirements necessary to keep the administration settlement as acceptable and legal completely.

Philipus M. Hadjon said that authority, procedure, and substance are three legal aspects to be fulfilled to make a decision or settlement to be legal. First, authority in this matter means that the official issuing the decision or settlement is indeed has the authority according to the regulation related; second, procedural aspect means that the settlement or decision is issued according to the process based on government disclosure; third,

13 Syafrudin Kalo. (2011). Aspek dan Implikasi Dalam Pendaftaran Tanah dan Penerbitan Sertifikat HakHak Atas Tanah, Jurnal Keadilan. Vol. 5 No.2. p. 1-2.

14

Ibid., p. 2.

15 Ibid., p. 2.

16 E. Utrects. (1963). Op. Cit., p. 104-105.

17 Syafrudin Kalo. (2011). Op. Cit., p. 2.

$18 \quad$ Ibid.

19 Boedi Djatmiko Hadjatmodjo.(2015). "Karakter Hukum Sertifikat Hak", http://sertifikattanah.blogspot.com/, accessed January 2015. 
substance aspect is regarding the object of the decision has no "error in re". "Authority and substance is the basic of formal legality. Based on formal legality, the presumptio iustae cause principle is created. Based on that, the provision in Article 67 (1) Indonesian Act number 5 of 1986 regarding Administration Court (as amended with Act number 51 of 2009) stated that: the charge doesn't prevent the related Institution or Administration to make decision/settlement. ${ }^{21}$

On the other hand, based on law, one decision which is not fulfilling the elements can be is lack of legal aspect in the making, so he decision is un-legal decision. E. Utrecht said that one decision with this kind of issue is not always an un-legal decision. There is decision which contain some deficiency but still is a legal decision. According to E. Utrecht, commonly, depending on the uncompleted requirement is included in bestaansvoorwaarde or not (bestaansvoorwaarde means an ultimate requirement to state if something exist or not). ${ }^{22}$ E. Utrecht said that the deficiency can be something essential and not essential. But it must be seen in its causalities that the decision is used for something (doelmatigheid) more important than to compare it with the procedure based on normative law (rechtsmatigheid). ${ }^{23}$

To know if one decision has deficiency included to essential or not essential part is necessary so that it can be said as legal or not legal. Following the theory of van der pot, there are 4 requirements: made by authorized official, there must not any legal damage, related to the form and procedure, the content and goal must be adjusted to the content and goal of the basic rule. Or as stated by Philipus M. Hadjon, there are 3 important aspects: authority, procedure and substance to be said as legal or verified decision or settlement.

In Administration Law, there are three cancelations of a decision or settlement:

1. Cancelled by law (nietigheid van rechtswege);

2. Absolutely cancelled (absoluut nietig);

3. Possibly cancelled decision (vernietigbaar). ${ }^{24}$

The canceled by law decision is one decision which content stated that it will considered as non-exist, without the need of the court to state it formally. ${ }^{25}$ But Utrecht himself explained in his footnotes that this is rarely happen, but in his personal opinion, ${ }^{26}$ cancelled by law need some action from the government or court or administration official to be made final.

A cancelled decision (nietig) is one action caused it is considered cancelled or 'Absoluut nietig'. ${ }^{27}$ Possibly canceled (vernietigbaar) means one action of Administration official which can be cancelled because its known to have deficiency. The action done and the impact is considered existed until the cancelation time is decided by the jury or other competent government institution (because of the deficiency). In law, the activity is still existed until the time of the cancelation(except when law mention some part is not legal). After the cancelation, the action is considered gone and -if possible -is managed to be deleted completely, including the impact. ${ }^{28}$ By other words, the decision which can be cancelled means a new decision can be cancelled after the authorized institution said so and it is not retroactive. So in law, the action and impact are still in effect until the issuance of cancellation unless regulated by the law. ${ }^{29}$

20 Philipus M Hadjon and Tatiek Sri Djatmiati. (2005). Argumentasi Hukum. Jogjakarta: Gajah Mada University Press. p. 83. They also explained that the validity term is a translation of the Dutch term "rechtmatigheid" (van bestuur). Rechtmatigheid = legality = legality. The scope of validity covers: 1. authority; 2. procedures; 3. substance.

21 Philipus M. Hadjon. (2004). Tolok Ukur Keabsahan Tindak Pemerintahan dan Keputusan Tata Usaha Negara, paper presented at the organization of House Legal Training Administrative Law and the Administrative Court on July 19-29. p. 1.

22 E. Utrecht. (1963). Op. Cit, p. 108.

23 E. Utrecht adapted by Bachsan Mustafa. (1990). Pokok-Pokok Hukum Administrasi Negara, Bandung: PT. Citra Aditya Bakti. p. 92.

24 E. Utrecht. (1963). Op. Cit., p. 109.

25 Ibid., p. 111.

26 Ibid., p. 110.

27 Ibid., p. 110.

28 Ibid., p. 110.

29 Boedi Djatmiko Hadjatmodjo. (2010). p. 1. 
As explained above, the authority, procedure, and substance are the legal principle to make a decision or settlement legal. This is according to Indonesian Cat number 5 of 1986 jo. Indonesian Act number 9 of 2004 regarding Administration Court, in Article 53 (1) and (2) it is mentioned that An individual or private law institution which purpose is damaged by a decision or settlement by administration may propose charge in written form to the Administration Court. The charge is written with the reason that the decision is contradicting the enforced rules, for example it has failure in authority, procedure, and substance, misuse of authority (de tournament de pouvoir) and unaccepted action.

Criminal Law Action in Right on Land Certificate Dispute

According to the concept of law and land provision, the decision of State Administration is the source of law and the evidence of the land right certificate with constitutive character, so, when dispute occurred regarding the ownership of the land, it is the absolute authority of the state administration which evidence is related to the failure in authority, procedure, and substance which are the turning point in the charges. It is different from the land certificate in declarative character, according to the right source, the ownership is admitted by the country so in the dispute process is handled in common court, where the evidence is related to the legality of the agreement aspect and certain object which is the basic charge in verification process in common court.

By that, the failure in issuing land certificate, beside administration law, private law, can be charged with criminal law if proven related to criminal action. The crime in land law can be crime in physical or legal data making, for example damaging landmark and change it to other place, providing fake data regarding the position of the land by related party such as the mayor or any party who has authority.

Article 52 Agrarian Law has demanded legal enforcement in land registration which can be charged with criminal law on certain actions. The practical rule of this provision is regulated in Indonesian Government Regulation number 10 of 1961 regarding land registration. This regulation asserted criminalization policy in Article 42 to 44. Criminalization policy in Government regulation is firmly appointed that criminal sanction on violation on the landmark is marked with certain mark according to the rule enacted by Agrarian Minister. The violation on certificate making regarding transferring the land right, providing new right on the land, or mortgage right without pointed by the Agrarian Minister, will be charged with imprisonment at most 3 (three) months and/or fine at most ten thousand rupiahs.

Criminalization policy in Indonesian Government Regulation number 10 of 1961 is no longer found in the amendment, Government Regulation number 24 of 1997 regarding Land Registration, so that the violation in land registration or the issuance of land certificate is more administrative. But then, even though the Government Regulation number 24 of 1997 doesn't regulate the criminal sanction to the violation in land registration and certificate issuance, but it doesn'tmean that the failure in land registration containing failure, fraud, and force in the physical and legal data cannot be charged with criminal law as regulated in Criminal Book of Law as lex generalis in criminal law.

In Criminal Book of Law, we can find provisions which able to filter the doer of the criminal in land registration in minimum, that is by using Article 265 (1) jo Article 407 (1), violation on Article 265 Criminal Book of Law regarding fake letter and Article 55 regarding Participation (delneming) jo Article 385 regarding Cheating (bedrog). With this criminal provision, the criminalization provision in the land law has been accommodated. But in investigation and legal enforcement, there are still technical difficulties so it is still hard to be implemented because it is also need to be proved that the action is done with failure (schuld). ${ }^{30}$ For example, in many cases, the physical data is not adjusted to the real situation. It need to be concerned if there are failures and intention by the party who make the landmark in the published land book.

\section{CONCLUSION}

Land Right Certificate issuance is implicated with legal certainty on the land right and also the dispute of land right in court:

1. Legal certainty of land registration in Indonesia has been regulated in Indonesian Act number 5 of 1960 regarding Agrarian Law, that in order to establish legal certainty, the Government ordered land registration to be conducted in every part of Indonesia according to the rules in government regulation. The Government here means the National Defense Institution. In implementing land registration or land right certificate as one of the strongest evidence for the owner. But the effort to legal certainty, tend to be not realized because of the disputes in court.

2. Land right certificate is one of the products of State Administration so State Administration Law can be put in effect on it. In Administration law, it is regulated that an individual or private legal institution which purpose is damaged by the decision of State administration can propose charge in written form to the

30 Ibid. 
Administration Court. The reason used is that the decision is contradicting the enforced law, for example regarding the authority, procedure, and substance (article explanation), authority misuse (de tournament de pouvoir) and the prevention of despotic action.

3. According to the concept of law and other provision of land right, land right certificate can be differed into constitutive character and declarative character, the dispute of constitutive one is under the authority of administration court, and the declarative is under the common court. By that, the failure in issuing the land right certificate can be charged with administration law, private law, and criminal law, if there are criminal aspects. But then, even though the Government Regulation number 24 of 1997 doesn't regulate the criminal sanction to the violation in land registration and certificate issuance, but it doesn'tmean that the failure in land registration containing failure, fraud, and force in the physical and legal data cannot be charged with criminal law as regulated in Criminal Book of Law as lex generalis in criminal law.

\section{BIBLIOGRAPHY}

[1] Chand, Hari. (1994). Modern Jurisprudence, Kuala Lumpur: International Law Book series.

[2] Curzon, L.B. (1999). Land Law. Seventh edition, Great Britain: Pearson Education Ltd.

[3] Deborah, Rock. (2001). Property Law \& Human Rights, First Published, London: Blackstone Press Limited Aldine Place.

[4] Dukemenier, Jesse. (1991-1992). Property. Gilbert Law Summaries, p. i.

[5] Hadjatmodjo, Boedi Djatmiko. (2015). "Karakter Hukum Sertifikat Hak", http://sertifikattanah.blogspot.com/, 10 May 2010, accessed January 2015.

[6] Hadjon, Philipus M dan Tatiek Sri Djatmiati. (2005). Argumentasi Hukum. Jogjakarta: Gajah Mada University Press.

[7] Hadjon, Philipus M. (2004). Tolok Ukur Keabsahan Tindak Pemerintahan dan Keputusan Tata Usaha Negara, seminar in House Legal Training Administration Law and PTUN, 19-29 July.

[8] Harsono, Boedi (2003). Hukum Agraria Indonesia, Sejarah Pembentukan Undang-Undang Pokok Agraria, Isi dan Pelaksanaannya, Jilid I Hukum Tanah Nasional, Jakarta: Djambatan.

[9] (1980). Beberapa Analisis Tentang Hukum Agrarian, bagian 3, Jakarta: Era study Club.

[10] Kalo, Syafrudin. (2011). Aspek dan Implikasi Dalam Pendaftaran Tanah dan Penerbitan Sertifikat HakHak Atas Tanah, Jurnal Keadilan. Vol. 5 No.2.

[11] Mustafa, Bachsan. (1990). Pokok-Pokok Hukum Administrasi Negara, Bandung: PT. Citra Aditya Bakti.

[12] Head of National Land Authority in Seminar regarding the effectiveness of " Rechtsverwerking"institution in preenting the weak negative publication system in land registration, held by Study Center of Agrarian Law, Law Faculty Trisakti University, 20 March 2002 Jakarta.

[13] Yamin, Muhammad. (2006). Problematika Mewujudkan Jaminan Kepastian Hukum Atas Tanah Dalam Pendaftaran Tanah, Professor speech in Agrarian Law field in Law Faculty, in front of open assembly, Universitas Sumatera Utara, Gelanggang Mahasiswa, USU, Medan. 